Jurnal Pendidikan Dasar, 6 (1) Juni 2018

\title{
PENGARUH MODEL PEMBELAJARAN GROUP INVESTIGATION (GI) BERBANTUAN MEDIA BOOKLET TERHADAP PEMAHAMAN KONSEP BAGUN RUANG PADA SISWA KELAS IV SDN 04 BATU AMPAR
}

\author{
Sinarti ${ }^{1}$, Mohamad Rif'at ${ }^{2}$, Mutazam $^{3}$ \\ ${ }^{1}$ Mahasiswa Program Studi PGSD \\ ${ }^{2}$ Dosen Uinversitas Tanjung Pura Pontianak \\ ${ }^{3}$ Dosen STKIP Melawi
}

Jl. RSUD Melawi km. 04 Kec. Nanga Pinoh Kab. Melawi Kalimantan Barat

Jl. Prof. Dr. H. Hadari Nawawi, Bansir Laut, Kota Pontianak, Kalimantan Barat

Sinar_nartistkipmelawi@yahoo.com, mohamad_rif'at@yahoo.com,

Nursammutazam@gmail.com

\begin{abstract}
The purpose of this research was to : (1) To acknowledge geometry concept understanding on the four ${ }^{\text {th }}$ grade students at SDN 04 Batu Ampar before and after using group investigation learning model with support of booklet. (2) To acknowledge the influence of group investigation learning model with support of booklet to geometry concept understanding on the four ${ }^{\text {th }}$ grade students at SDN 04 Batu Ampar. (3) To acknowledge the influence percentage group investigation learning model with support of booklet to geometry concept understanding on the four ${ }^{\text {th }}$ grade students at SDN 04 Batu Ampar. This reseacrh was a pre experimental design, and this design is one group pretest-postest. This research did to the four ${ }^{\text {th }}$ grade students at SDN 04 Batu Ampar, there were have 22 students (13 boys and 9 girls). The result of this research : (1) The student's geometry concept understanding before and after using group investigation learning model with support of booklet was different. (2) This research shown that there was a significant influence from group investigation with support of booklet to geometry concept understanding on the four ${ }^{\text {th }}$ grade students at SDN 04 Batu Ampar. (3) The influence of group investigation learning model with support of booklet to geometry concept understanding on the four ${ }^{\text {th }}$ grade students at SDN 04 Batu Ampar was 49,53\%.
\end{abstract}

Keywords : group investigation, booklet, concept understanding, geometry.

Abstrak: Penelitian ini bertujuan untuk (1) Mengetahui pemahaman konsep
bangun ruang siswa kelas IV SDN 04 Batu Ampar antara sebelum dan sesudah
menggunakan model pembelajaran group investigation berbantuan media
booklet. (2) Mengetahui pengaruh model pembelajaran group investigation
berbantuan media booklet terhadap pemahaman konsep bangun ruang siswa
kelas IV SDN 04 Batu Ampar. (3) Mengetahui seberapa besar pengaruh model
pembelajaran group investigation berbantuan media booklet terhadap
pemahaman konsep bangun ruang siswa kelas IV SDN 04 Batu Ampar. Jenis
penelitian ini adalah Pra Eksperimen (Pre Experimental Design), dengan
bentuk one group pretest-postest design. Penelitian ini dilakukan terhadap
siswa kelas IV SDN 04 Batu Ampar yang berjumlah 22 orang, terdiri dari 13
siswa laki-laki dan 9 siswa perempuan. Hasil penelitian (1) Pemahaman 10| J P D, p - I S S N : $2252-8156$, e - I S S N : $2579-3993$ 
konsep siswa antara sebelum dan sesudah menggunakan model pembelajaran group investigation berbantuan media booklet adalah berbeda, (2) Terdapat pengaruh yang signifikan dari model pembelajaran group investigation berbantuan media booklet terhadap pemahaman konsep bangun ruang siswa kelas IV SDN 04 Batu Ampar, (3) Pengaruh dari model pembelajaran group investigation berbantuan media booklet terhadap pemahaman konsep bangun ruang siswa kelas IV SDN 04 Batu Ampar adalah sebesar 49,53\%.

Kata Kunci : group investigation, booklet, pemahaman konsep, bangun ruang.

ISA (program for international
studen assesment) adalah salah satu program yang digagas oleh OECD (the organisation for economic cooperation and development). Tugasnya mengevaluasi materi dibidang sains, membaca dan matematika yang ditujukan pada siswasiswi dibeberapa negara di dunia (Musfiroh dalam LITERA, Volume 15 No 1). Pada tahun 2015 hasil tes dan survey yang melibatkan 70 negara di dunia termasuk Indonesia, menyatakan bahwa rata-rata nilai matematika siswa Indonesia pada program PISA adalah sebesar 386 dari 490. Hal tersebut menyebabkan Indonesia meraih peringkat 63 dari 70 negara pada mata pelajaran Matematika. Nilai Matematika pada Ujian Nasional (UN) tingkat Sekolah Menengah Pertama (SMP) di Indonesia pada tahun 2016 juga mengalami penurunan sebesar 6,04 poin (Permatasari, 2017 : 1). Penurunan pada nilai tersebut juga terjadi pada jenjang Sekolah Dasar (SD). Hal tersebut membuktikan bahwa sebagian besar siswa Indonesia mengalami kesulitan dalam mengerjakan soal-soal matematika.
Data hasil observasi yang telah dilakukan peneliti pada siswa kelas IV SDN 04 Batu Ampar menunjukkan bahwa sebagian besar siswa menganggap belajar matematika terkesan sukar dikarenakan sifatnya yang abstrak, rumit, dan membingungkan, sehingga siswa menjadi kesulitan dalam memahami konsep. Salah satu materi yang sukar dipahami oleh siswa adalah materi bangun ruang. Pada materi ini siswa kesulitan dalam mengenal sifat atau ciri dari bangun ruang, serta membedakan tinggi, panjang, dan lebar dari bangun ruang yang berimbas pada ketidakpahaman siswa dalam menghitung luas permukaan dan keliling dari bangun ruang. Mengatasi hal tersebut maka peneliti mencoba mencari solusi yang tepat agar dapat mengurangi kesulitan siswa dalam memahami konsep bangun ruang. Alternatif solusi yang dipilih oleh peneliti adalah dengan menerapkan model pembelajaran group investigation berbantuan media booklet.

Model pembelajaran group investigation adalah suatu model pembelajaran yang melibatkan kelompok 
kecil dimana siswa bekerja menggunakan penemuan kooperatif, perencanaan, proyek, dan diskusi kelompok, kemudian mempresentasikan penemuannya tersebut didepan kelas. Sedangkan booklet adalah sebuah media berbentuk buku berukuran kecil yang berisi gambar-gambar dan tulisan yang berisi penjelasan tentang suatu materi. Satmoko (2006 : 2) menyatakan bahwa booklet adalah sebuah buku kecil yang memiliki paling sedikit lima halaman tetapi tidak lebih dari empat puluh delapan halaman diluar hitungan sampul.

Model pembelajaran group investigation berbantuan media booklet adalah suatu model pembelajaran yang diterapkan dengan disertai penggunaan media berupa catatan-catatan kecil yang bertujuan untuk menarik minat belajar siswa, serta untuk melibatkan siswa secara aktif dalam proses pembelajarannya sehingga siswa menjadi lebih mudah dalam memahami suatu konsep. Dengan menerapkan model pembelajaran group investigation berbantuan media booklet diharapkan dapat mempengaruhi minat dan motivasi siswa dalam mempelajari bangun ruang, sehingga siswa memperoleh hasil yang maksimal baik dalam proses pemahaman konsep ataupun hasil belajarnya. Dengan demikian maka peneliti merasa perlu untuk mengadakan suatu penelitian dengan judul "Pengaruh Model Pembelajaran Group Investigation
Berbantuan Media Booklet Terhadap Pemahaman Konsep Bangun Ruang Pada Siswa Kelas IV SDN 04 Batu Ampar”.

\section{METODE PENELITIAN}

Jenis penelitian yang digunakan dalam penelitian ini adalah Pre Experimental Design dengan bentuk One Group Pretest-Postest Design. Pada desain ini terdapat pretest sebelum perlakuan, dengan demikian maka hasil perlakuan dapat diketahui lebih akurat karena dapat membandingkan dengan keadaan sebelum diberi perlakuan (Sugiyono, 2015 : 74). Variabel bebas dalam penelitian ini adalah model pembelajaran group investigation berbantuan media booklet, dan variabel terikatnya adalah pemahaman konsep bangun ruang siswa kelas IV SDN 04 Batu Ampar.

Penelitian ini dilaksanakan di SDN 04 Batu Ampar pada tanggal 29, 30, 31 Januari, serta pada tanggal 6 dan 7 Februari 2018. Pada pertemuan pertama peneliti memberikan pretest kepada siswa, pertemuan ke dua dan ke tiga peneliti memberikan perlakuan dengan menerapkan model pembelajaran group investigatian berbantuan media booklet. Pertemuan ke empat peneliti bersama siswa melakukan evaluasi secara keseluruhan tentang apa yang telah dipelajari pada pertemuan ke dua dan ke tiga, kemudian pada pertemuan ke lima peneliti memberikan postest kepada siswa. 
Subjek dalam penelitian ini adalah seluruh siswa kelas IV SDN 04 Batu Ampar yang berjumlah 22 siswa, terdiri dari 9 siswa perempuan dan 13 siswa laki-laki. Sedangkan objek dalam penelitian ini adalah model pembelajaran group investigation berbantuan media booklet dan pemahaman konsep bangun ruang siswa.

Teknik pengumpulan data dalam penelitian ini adalah teknik pengukuran dan teknik dokumentasi dengan instrumen penelitian berupa tes tertulis berbentuk esai (uraian) berjumlah lima soal. Teknik pengukuran bertujuan untuk mengetahui rata-rata pemahaman konsep siswa sebelum dan sesudah diberikan perlakuan dengan model pembelajaran group investigation berbantuan media booklet, sedangkan teknik dokumentasi adalah pelengkap dari penggunaan teknik pengukuran.

Validitas dalam penelitian ini menggunakan validitas isi (kualitatif) dan validitas empirik (kuantitatif) dengan rumus korelasi product moment, sedangkan reliabilitas dalam penelitian ini dihitung dengan menggunakan rumus alpha. Uji coba soal dilaksanakan di SDN 18 Tubung pada 26 Januari 2018. Setelah dilaksanakannya uji coba soal maka kemudian peneliti menganalisis tingkat validitas, reliabilitas, daya pembeda, dan tingkat kesukaran dari instrumen yang digunakan. Berdasarkan analisis terhadap hasil uji coba soal maka ditarik kesimpulan bahwa soal pretest dan postest yang telah di uji coba layak digunakan dalam penelitian.

Analisis terhadap data penelitian dilakukan setelah dilaksanakannya penelitian. Analisis data dalam penelitian ini menggunakan penghitungan statistik deskriptif, analisis regresi linier sederhana, dan effect size. Sebelum melakukan analisis regresi linier sederhana, data terlebih dahulu diuji normalitas, homogenitas, dan linieritasnya sebagai syarat untuk melakukan analisis regresi tersebut. Uji normalitas dalam penelitian ini menggunakan uji liliefors, sedangkan uji homogenitas menggunakan uji barlett.

\section{HASIL DAN PEMBAHASAN}

Hasil pengolahan data dengan menggunakan statistik deskriptif menunjukkan bahwa jumlah nilai dari keseluruhan siswa pada pretest adalah sebesar 1087 dengan rata-rata nilai sebesar 49.41, nilai tertinggi adalah 56, nilai terendah adalah 37 , dan standar deviasinya sebesar 5.63, sedangkan pada postest diperoleh keseluruhan nilai sebesar 1726, dengan rata-rata nilai sebesar 78.45 , nilai tertinggi adalah 95, nilai terendah adalah 65, dan standar deviasinya sebesar 11.16, setelah dianalisis dengan statistik deskriptif peneliti kemudian melakukan uji normalitas, homogenitas dan linieraitas 13| J P D, p - I S S N : $2252-8156$, e - I S S N : $2579-3993$ 
terhadap data hasil penelitian. Suatu data dikatakan normal apabilia L hitung $<\mathrm{L}$ tabel, sedangkan suatu data dikatakan homogen apabili $\mathrm{X}$ hitung $<\mathrm{X}$ tabel. Data juga dikatakan linier apabila nilai signifikansinya diatas 0,05 . Berdasarkan uji normalitas, homogenitas, dan uji linieritas yang telah dilakukan maka data hasil penelitian dimyatakan normal, homogen, dan, linier. Setelah dilakukan ke tiga uji tersebut, maka kemudian dilakukan analisis regresi linier sederhana.

Analisis regresi linier sederhana dilakukan untuk mengetahui apakah terdapat pengaruh dari variabel bebas (model pembelajaran group investigation berbantuan media booklet) terhadap variabel terikat (pemahaman konsep bangun ruang). Hasil analisis regresi linier sederhana menunjukkan bahwa terdapat pengaruh yang signifikan dari variabel bebas (model pembelajaran group investigation berbantuan media booklet) terhadap variabel terikat (pemahaman konsep bangun ruang). Untuk mengetahui seberapa besar pengaruh yang dari model pembelajaran group investigation berbantuan media booklet terhadap pemahaman konsep bangun ruang maka dilakukan penghitungan dengan menggunakan rumus effect size. Dari penghitungan dengan rumus effect size maka besarnya pengaruh yang ditimbulkan adalah sebesar 2,60 dengan kriteria tinggi.
Angka tersebut apabila dilihat dengan menggunakan tabel $\mathrm{Z}$ maka akan menghasilkan nilai sebesar 0,4953 dan jika diubah kedalam bentuk persen (\%) maka besarnya pengaruh adalah sebesar $49,53 \%$.

Pembelajaran dengan menggunakan model pembelajaran group investihation berbantuan media booklet terbukti dapat mempengaruhi pemahaman konsep bangun ruang pada siswa kelas IV SDN 04 Batu Ampar, dan besarnya pengaruh yang ditimbulkan adalah 49,53\%. Adapun faktor yang menyebabkan siswa dapat mengetahui, mengenal, dan memahami konsep bangun ruang dalam penelitian ini adalah penggunaan model pembelajaran group investigation yang menuntun siswa belajar dengan menggunakan penemuan kooperatif, perencanaan, proyek, dan diskusi kelompok. Dengan demikian maka siswa akan lebih mudah dalam mengingat apa yang telah dipelajarinya. Selain penggunaan model pembelajaran group investigation, faktor lain yang menyebabkan siswa dapat mengetahui, mengenal, dan memahami konsep bangun ruang adalah Penggunaan media booklet sebagai penunjang pembelajaran siswa dalam kegiatan investigasi dalam kelompoknya, sehingga siswa dapat dengan mudah mempelajari konsep dari bangun ruang. 


\section{SIMPULAN}

Kemampuan awal siswa sebelum diterapkan model pembelajaran group investigation berbantuan media booklet terlihat dari nilai pretest siswa. Dari hasil pretest tersebut, ditarik kesimpulan bahwa sebagian besar siswa kesulitan dalam mengenal dan membedakan bentuk dari bangun ruang kkubus dan bangun ruang balok. Akantetapi setelah menggunakan model pembelajaran group investigation berbantuan media booklet, siswa menjadi dapat mengenal dan membedakan bentuk dari bangun ruang kubus dan bangun ruang balok.

Siswa sebelum diterapkan model pembelajaran group investigation berbantuan media booklet cenderung kesulitan dalam mengenal sifat atau ciri dari bangun kubus dan balok, akantetapi setelah diterapkan model pembelajaran group investigation berbantuan media booklet siswa mulai dapat mengenal sifat dan ciri dari bangun ruang kubus dan bangun ruang balok.

Model pembelajaran group investigation berbantuan media booklet setelah diterapkan pada siswa kelas IV SDN 04 Batu Ampar, maka dapat ditarik kesimpulan bahwa model pembelajaran group investigation berbantuan media booklet dapat mempengaruhi pemahaman konsep bangun ruang siswa. Pengaruh dari model pembelajaran group investigation berbantuan media booklet dapat dikategorikan positif. Siswa sebelum diterapkan model pembelajaran group investigation berbantuan media booklet dapat dikatakan belum memahami konsep dari bangun ruang kubus dan balok, tetapi setelah diterapkan model pembelajaran group investigation berbantuan media booklet siswa terbukti telah memahami konsep dari bangun ruang kubus dan balok.

\section{DAFTAR PUSTAKA}

Musfiroh, T. \& Beniati. 2016. "Konstruk Kompetensi Literasi untuk Siswa SD”. LITERA. Volume 15, nomor 1, tahun 2016. Yogyakarta : Universitas Negeri Yogyakarta.

Permatasari, F. 2017. Deskripsi Kesulitan Belajar Matematika Siswa Keals VIII SMP Muhammadiyah Tambak Pada Materi Bangun Ruang Sisi Datar. Purwokerto:

Universitas Muhammadiyah.

Satmoko. 2006. "Pengaruh Bahasa Booklet pada Peningkatan Pengetahuan Peternak Sapi”. Jurnal Penyuluhan. Volume 2, Nomor 2, tahun 2006. Semarang.

Shoimin. 2014. 68 Model Pembelajaran Innovatif dalam Kurikulum 2013. Yogyakarta : Ar-Ruzz Media.

Sugiyono. 2015. Metode Penelitian dan Pengembangan: Research and Develovment: untuk Bidang 
Jurnal Pendidikan Dasar, 6 (1) Juni 2018

Pendidikan, Manajemen, Sosial, dan

Teknik. Bandung : Alfabeta

16| J P D, p - I S S N : 2252 - 8156 , e - I S S N : 2579 - 3993 